DOI: $10.19195 / 0524-4544.325 .8$

TOMASZ DOLATA

ORCID: 0000-0003-2028-0671

Uniwersytet Wrocławski

tomasz.dolata@uwr.edu.pl

\title{
Działalność Urzędu Patentowego w zakresie ochrony znaków towarowych na podstawie rozporządzenia o ochronie wynalazków, wzorów i znaków towarowych z 1928 roku - zarys problematyki
}

Ochrona wynalazków, wzorów i znaków towarowych, czyli szeroko rozumiane prawo patentowe, oprócz przepisów dotyczących zwalczania nieuczciwej konkurencji oraz problematyki prawa do firmy, stanowi część dobrze rozwiniętego w II Rzeczypospolitej prawa własności przemysłowej. Ustawodawca polski szybko podjął próby uregulowania kwestii związanych z prawem patentowym. Pierwszymi aktami prawnymi w II Rzeczypospolitej normującymi tę problematykę były: dekret tymczasowy o Urzędzie Patentowym z dnia 13 grudnia 1918 roku $^{1}$ oraz trzy dekrety datowane na dzień 4 lutego 1919 roku o patentach na wynalazki ${ }^{2}$, o ochronie wzorów rysunkowych i modeli ${ }^{3}$ i o ochronie znaków towarowych ${ }^{4}$. Dekrety te uchyliły obowiązujące w poszczególnych dzielnicach przepisy państw zaborczych ${ }^{5}$.

1 Dz.P.P.P. nr 21, poz. 66. Niektóre postanowienia tego dekretu znowelizowano ustawą z dnia 2 sierpnia 1919 roku o zmianach w dekrecie o Urzędzie Patentowym (Dz.P.P.P. nr 67, poz. 410).

2 Dz.P.P.P. nr 13, poz. 137.

3 Dz.P.P.P. nr 13, poz. 138.

${ }^{4}$ Dz.P.P.P. nr 13, poz. 139. Ponadto warto nadmienić, iż w celu zabezpieczenia odpowiedniego funkcjonowania rozwiązań zawartych w wymienionych dekretach wydano wiele innych przepisów prawnych, które podaje W. Czempińska, Rozwój pojęć o ochronie praw wynalazcy, Warszawa 1931, s. 92-94. Zob. także R. Hausner, Skorowidz dekretów, ustaw, rozporządzeń i okólników, Warszawa 1920, t. 1, s. 30-31.

5 Zob. bliżej E.S. Mieroszewicz, Ustawa o ochronie wynalazków, wzorów i znaków towarowych, Warszawa 1924, s. 5-8. Zob. także T. Dolata, Początki polskiego ustawodawstwa z zakresu

Prawo 325, 2018

(C) for this edition by CNS 
Dość szybko okazało się jednak, że wprowadzone po odzyskaniu niepodległości regulacje nie pasują do rzeczywistości prawnej odrodzonego państwa polskiego ${ }^{6}$, dlatego też rozpoczęły się żmudne prace nad projektem nowych rozwią$z^{2}{ }^{7}$. W rezultacie do skutku doszła ustawa z dnia 5 lutego 1924 roku o ochronie wynalazków, wzorów i znaków towarowych ${ }^{8}$, która zupełnie zmieniła koncepcję regulacji tej problematyki, gdyż połączyła w jednym akcie prawnym rozrzucone dotychczas w kilku dekretach kwestie związane z wynalazkami, wzorami, znakami towarowymi oraz organem rejestrującym — Urzędem Patentowym. Ponadto ustawa przyjęła zupełnie inny model jurydyczny (przeszła z systemu germańskiego na romański) ${ }^{9}$. Następnie w związku z przystąpieniem Polski do zmienionej konwencji paryskiej o ochronie własności przemysłowej (tekst haski z 1925 roku $^{10}$ ), ustawa o ochronie wynalazków, wzorów i znaków towarowych z dnia 5 lutego 1924 roku została uchylona ${ }^{11}$. Zastąpiło ją rozporządzenie Prezydenta Rzeczypospolitej o ochronie wynalazków, wzorów i znaków towarowych z dnia 22 marca 1928 roku $^{12}$, które w stosunku do ustawy charakteryzowało się jedynie pewnymi, niewielkimi zmianami w warstwie merytorycznej i redakcyjnej. Najważniejsze

ochrony wynalazków, wzorów i znaków towarowych $w$ dwudziestoleciu międzywojennym, „Studia Historycznoprawne" 314, 2012, s. 112.

6 Zob. bliżej E.S. Mieroszewicz, op. cit., s. 8-9.

7 Zob. bliżej T. Dolata, Geneza, budowa i ważniejsze rozwiązania ustawy o ochronie wynalazków, wzorów i znaków towarowych z dnia 5 lutego 1924 roku, „Studia Historycznoprawne” 315/2, 2013, s. 127-131.

${ }^{8}$ Dz.U. RP Nr 31, poz. 306. Autorem ustawy był jeden z najwybitniejszych polskich znawców prawa własności intelektualnej — prof. Fryderyk Zoll.

${ }^{9}$ Kwestia ta doskonale znana jest współczesnej doktrynie. Systemy te charakteryzuje L. Górnicki, Prawa na dobrach niematerialnych, [w:] Synteza prawa polskiego 1918-1939, red. T. Guz, J. Głuchowski, M.R. Pałubska, Warszawa 2013, s. 370-372; idem, Rozwój idei ochrony praw własności intelektualnej do II wojny światowej, „Zeszyty Naukowe Wyższej Szkoły Informatyki i Zarządzania »Copernicus« we Wrocławiu”, 2006, nr 3, s. 21-22; idem, Wptyw obcych ustawodawstw i doktryny prawa na polska kodyfikacje prawa prywatnego w II RP, [w:] Korzenie i tradycje współczesnego prawa cywilnego w zjednoczonej Europie, red. A. Karabowicz, M. Stus, (,ZNUJ. Towarzystwo Biblioteki Słuchaczów Prawa. Zeszyty Prawnicze" z. 13), Kraków 2005, s. 73-74.

10 Konwencja związkowa paryska z dnia 20 marca 1883 roku o ochronie własności przemysłowej, przejrzana w Brukseli dnia 14 grudnia 1900 roku, w Waszyngtonie dnia 2 czerwca 1911 roku i w Hadze dnia 6 listopada 1925 roku (Dz.U. RP z 1932 r., Nr 2, poz. 8), ratyfikowana zgodnie z ustawą z dnia 17 marca 1931 roku (Dz.U. RP Nr 37, poz. 277) (dalej: „konwencja paryska”).

11 Uchylono także przepisy z nią powiązane: ustawę z dnia 19 grudnia 1924 roku o zmianach opłat przewidzianych w ustawie z dnia 5 lutego 1924 roku o ochronie wynalazków, wzorów i znaków towarowych (Dz.U. RP z 1925 r. Nr 5, poz. 41) oraz rozporządzenie Prezydenta Rzeczypospolitej z dnia 24 czerwca 1927 roku zmieniające niektóre postanowienia ustawy z dnia 5 lutego 1924 roku o ochronie wynalazków, wzorów i znaków towarowych (Dz.U. RP Nr 61, poz. 537).

12 Dz.U. RP. Nr 39, poz. 384 i cały zbiór aktów wykonawczych, które wymienia: S.M. Grzybowski, Ochrona wynalazków, wzorów i znaków towarowych, „Encyklopedia Podręczna Prawa Prywatnego", [b.m.w., b.r.w.], odbitka, z. 18 i 19, s. 5. 
uregulowania (struktura ustawy czy konstrukcje jurydyczne) pozostały jednak niezmienione ${ }^{13}$.

Celem tego opracowania jest omówienie działalności Urzędu Patentowego ${ }^{14}$ w zakresie ochrony znaków towarowych pod rządami wspomnianego rozporządzenia $^{15}$, które $\mathrm{z}$ uwagi na najdłuższy okres obowiązywania stanowi najbardziej miarodajną podstawę do zbadania tej problematyki ${ }^{16}$. Poza zakresem tego opracowania pozostaje problem szczegółowego omówienia kwestii dotyczących konstrukcji teoretycznych wykorzystanych przez ustawodawcę do ochrony znaków towarowych. Co prawda zagadnienia te w oczywisty sposób łączą się z omawianą problematyką, stanowią jednak odrębny temat badawczy, stąd też zostaną jedynie zasygnalizowane.

Przedstawiając podstawę prawną funkcjonowania polskiego Urzędu Patentowego $\mathrm{w}$ interesującym nas okresie, warto przybliżyć strukturę rozporządzenia z 1928 roku. Akt ten składał się z 245 artykułów i dzielił na cztery części, z których:

— pierwsza — o patentach na wynalazki (art. 1-86) zawierała się w siedmiu rozdziałach,

13 Zob. bliżej S.M. Grzybowski, op. cit., s. 4-5; M. Słomski, Historia rzecznictwa patentowego $w$ Polsce, Kraków 1997, s. 54.

$14 \mathrm{Na}$ podstawie art. 12 konwencji paryskiej każdy z krajów zawierających tę umowę zobowiązany był do ustanowienia odrębnego urzędu do spraw własności przemysłowej i centralnego biura zgłoszeń w celu podawania do ogólnej wiadomości informacji dotyczących patentów na wynalazki i innych rodzajów tytułów ochronnych, do których stosowano tę konwencję. Zob. bliżej L. Gruszow, Rozwój działalności urzędów patentowych, [w:] Księga pamiątkowa z okazji 85-lecia ochrony własności przemystowej w Polsce, red. E. Wikło, Warszawa 2003, s. 46-47.

15 Opracowanie to jest wstępem do głębszych badań dotyczących tytułowej problematyki.

16 Rozporządzenie to stanowiło podstawę prawną działania Urzędu Patentowego od 1928 roku aż do wybuchu II wojny światowej. Poprzednio obowiązująca ustawa funkcjonowała w obiegu prawnym tylko 4 lata (1924-1928), natomiast na podstawie dekretów z 1919 roku (obowiązujących do 1924 roku) aktywność Urzędu Patentowego w zakresie rejestracji znaków towarowych była zerowa (pomimo zgłoszenia w samym tylko 1922 roku 2124 wniosków Urząd nie zarejestrował żadnego znaku towarowego). Rejestrację znaków towarowych rozpoczęto dopiero w 1924 roku (po wejściu w życie ustawy z dnia 5 lutego 1924 roku). Zob. bliżej Statystyka ogólna ochrony własności przemystowej za 1922 r., „Wiadomości Urzędu Patentowego” 1924, z. 8, s. 419. Zob. także M. Słomski, op. cit., s. 49-50; F. Zoll, Prawa na dobrach niematerialnych, [w:] Encyklopedia podręczna prawa publicznego, red. Z. Cybichowski, t. 2, Warszawa [b.r.w.], s. 697. Trzeba obiektywnie podkreślić, że z biegiem czasu rola Urzędu Patentowego rosła. Mówił o tym w grudniu 1926 roku Minister Przemysłu i Handlu E. Kwiatkowski podczas swojego przemówienia w Komisji Budżetowej Sejmu. Zob. bliżej Dwa przemówienia w Sejmie Ministra Przemystu i Handlu inż. Eugeniusza Kwiatkowskiego, [w:] Polityka gospodarcza. Zagadnienia administracji, t. 1, Warszawa 1928, s. XXXV. Pozytywną opinię o Urzędzie Patentowym po wejściu w życie ustawy z 1924 roku prezentował S. Czaykowski, który pisał: „Urząd ten rozpoczął swą pełną działalność w kwietniu r. 1924 [...]. Od tej chwili sprawy ochrony własności przemysłowej i handlowej weszły w Polsce na tory normalne; niezmiernie ważna dziedzina administracji, zgoła specjalną w nowoczesnym państwie darzona uwagą, odżyła z tą chwilą na ziemiach całej Rzeczypospolitej”, idem, Ochrona własności przemystowej i handlowej, [w:] Polityka gospodarcza..., s. 59. 
— druga — o wzorach użytkowych i zdobniczych (art. 87-173) również zawierała się w siedmiu rozdziałach,

— trzecia — o znakach towarowych (art. 174-231), składała się z ośmiu rozdziałów ${ }^{17}$,

- czwarta - Urząd Patentowy Rzeczypospolitej Polskiej. Rzecznicy patentowi. Postanowienia końcowe (art. 232-245), mieściła się w trzech rozdziałach.

Z uwagi na zakreślony temat rozważań warto przyjrzeć się rozwiązaniom dotyczącym znaków towarowych (część trzecia rozporządzenia) oraz usytuowaniu Urzędu Patentowego w systemie ochrony znaków towarowych (część czwarta rozporządzenia). Przepisy te regulowały bowiem tak zasadnicze z punktu widzenia tematu rozważań kwestie, jak choćby definicję znaków towarowych i inne przepisy materialnoprawne, postępowanie dotyczące ochrony praw ze znaku towarowego czy strukturę Urzędu Patentowego.

W części trzeciej — o znakach towarowych — zawarto zatem przepisy regulujące kwestie:

- powstania prawa, ograniczenia jego mocy, unieważnienia i wygaśnięcia (rozdz. 1, art. 174-184);

— własności i innych praw rzeczowych na znaku towarowym (rozdz. 2, art. 185-187);

— ochrony praw z rejestracji znaku towarowego (rozdz. 3, art. 188-191);

- ochrony wolności handlowej (rozdz. 4, art. 192);

— postępowania i właściwości władz (rozdz. 5, art. 193-212);

— opłat (rozdz. 6, art. 213-217);

— znaków związkowych (rozdz. 7, art. 218-223);

— przepisów przejściowych i międzynarodowych (rozdz. 8, art. 224-231).

Natomiast w części czwartej znalazły się przepisy dotyczące:

— Urzędu Patentowego Rzeczypospolitej Polskiej (rozdz. 1, art. 232-239);

— rzeczników patentowych (rozdz. 2, art. 240-243);

— postanowień końcowych (rozdz. 3, art. 244-245).

Z punktu widzenia konstrukcji jurydycznej jednym z najważniejszych przepisów był art. 174 rozporządzenia, w którym zawarto dość ogólną definicję znaku towarowego. Zgodnie z jego treścią znakami towarowymi mogły być wszelkie rysunki, obrazki, słowa, litery, liczby, formy plastyczne itp. wskazujące odbiorcom,

17 Zdaniem S.M. Grzybowskiego przepisy o znakach towarowych powinny być zamieszczone w osobnej ustawie dotyczącej praw na przedsiębiorstwie. Wynikało to, według niego, z faktu, iż w przypadku ochrony wynalazków i wzorów dobrem prawnie chronionym był sam wynalazek i wzór, natomiast przy znakach towarowych prawo chroniło zupełnie inne dobro, jakim było przedsiębiorstwo. Problematyka znaków towarowych nie została odrębnie uregulowana z dwóch powodów. Po pierwsze, z przyczyn pragmatycznych, gdyż wynalazki, wzory i znaki towarowe łączyła właściwość Urzędu Patentowego jako organu powołanego do działań w kierunku ich ochrony. Po drugie, z przyczyn obiektywnych wynikających z tego, iż nie udało się wypracować jednolitego i łącznego ujęcia całości praw na przedsiębiorstwie w formie ustawowej. Zob. bliżej S.M. Grzybowski, op. cit., s. 27. 
że towar pochodzi z określonego przedsiębiorstwa ${ }^{18}$. Wyłączne prawo oznaczania towarów znakami powstawało, co do zasady, przez zarejestrowanie znaku ${ }^{19}$ i rozciągało się na cały obszar Rzeczypospolitej Polskiej. Z możliwości rejestracji wyłączono między innymi znaki:

— niemające dostatecznych cech odróżniających (art. 177 ust. 1 lit. a);

- naruszające prawa pewnych osób (do nazwiska, do firmy, do wizerunku) albo sprzeczne z obowiązującym prawem lub dobrymi obyczajami (art. 177 ust. 1 lit. b);

- mogące wprowadzić w błąd odbiorców co do pochodzenia, rodzaju, jakości towaru albo oznaczeń przedsiębiorstwa (art. 177 ust. 1 lit. c) $)^{20}$.

18 Wyliczenie to miało charakter jedynie przykładowy. Autorzy jedynego liczącego się w doktrynie przedwojennego komentarza poświęconego temu rozporządzeniu wsazywali: „Wyliczenie znaków towarowych, umieszczone w ust. 1 nin. art. (w nawiasie), zawiera tylko ogólne wskazówki i nie wyczerpuje wszystkich odmian zewnętrznych form, które mogą służyć do oznaczania towarów" - A. Ponikło, J. Gutowski, Polskie prawo patentowe. Rozporządzenie Prezydenta Rzeczypospolitej z dnia 22 marca 1928 r. o ochronie wynalazków, wzorów i znaków towarowych. Komentarz z przedmowa i wstepem prof. d-ra Fryderyka Zolla, Warszawa 1935, s. 178. Tak samo F. Zoll, Opinja prawna profesora dra Fryderyka Zolla o prawie firmy Maggi do wytacznego używania charakterystycznych flaszek $w$ handlu przyprawa do zup, Poznań 1931, s. 11-12. Uczony ten, powołując się na wskazany w opinii stan faktyczny, dowodził, że znakiem towarowym mogła być też odpowiednio stylizowana butelka. Pisał on: ,,charakterystyczna forma flaszki może wskazywać odbiorcom na pochodzenie towaru (płynu), w niej znajdującego się, z pewnego przedsiębiorstwa i w tem znaczeniu indywidualizować towar i przedsiębiorstwo, przeto może być znakiem towarowym w znaczeniu ustaw o znakach towarowych i doznawać ochrony prawnej jako znak towarowy pod warunkiem rejestracji”. Ibidem, s. 6.

19 Niezarejestrowany znak towarowy mógł podlegać prawnej ochronie na podstawie ustawy o zwalczaniu nieuczciwej konkurencji z dnia 2 sierpnia 1926 roku (tekst jedn. Dz.U. RP z 1930 r. $\mathrm{Nr} 56$, poz. 467). Relacje prawne pomiędzy ustawą o zwalczaniu nieuczciwej konkurencji a prawem o ochronie wynalazków, wzorów i znaków towarowych z dnia 22 marca 1928 roku opisał R. Paszkowski, Powstanie prawa do znaku towarowego a ustawa o zwalczaniu nieuczciwej konkurencji, Warszawa 1935, s. 33-39. Zob. także T. Dolata, Polska ustawa o zwalczaniu nieuczciwej konkurencji z 1926 r. a inne regulacje z zakresu praw na dobrach niematerialnych, [w:] Studia z dziejów państwa i prawa polskiego, t. 12, Kraków-Lublin-Łódź 2009, s. 269-275.

20 Ponadto nieważne było nabycie poprzez rejestrację prawa do znaku identycznego ze znakiem już zarejestrowanym na rzecz innego przedsiębiorstwa dla tego samego rodzaju towaru (art. 179). Za identyczny uważano znak, który różnił się tak nieznacznie od wcześniejszego, że odbiorcy mogliby być wprowadzeni w błąd co do przedsiębiorstwa, z którego pochodził towar (art. 181). W tym zakresie pojawiło się dość bogate orzecznictwo, które doprecyzowało uregulowania rozporządzenia. Zob. bliżej wyrok Izby Karnej SN z dnia 22 kwietnia 1938 roku (3 K. 2291/37), „Orzecznictwo Sądów Najwyższych w sprawach podatkowych i administracyjnych” 2, 1938, s. 996-999: „Podobieństwo znaków towarowych (art. 181 cyt. rozp.) polega, bez względu na różnice szczegółów, na ogólnym wrażeniu wzrokowym, zdolnym złudzić nabywcę co do pochodzenia towaru”. Zob. także wyrok NTA z dnia 23 października 1936 roku (1. rej. 6560/34) w sprawie firmy Georg Schicht A. w Ujściu n. Łabą (Czechosłowacja) przeciw Wydziałowi Odwoławczemu Urzędu Patentowego w przedmiocie unieważnienia rejestracji znaku towarowego, „Orzecznictwo Sądów Najwyższych w sprawach podatkowych i administracyjnych” 1, 1938, s. 80-83: „W myśl art. 181 rozp. Prez. z r. 1928 nie wystarcza stwierdzenie w ogóle podobieństwa względnie wspólności, choćby bardzo nawet licznych cech

Prawo 325, 2018

(C) for this edition by CNS 
Organem właściwym do podejmowania czynności ${ }^{21} \mathrm{w}$ zakresie ochrony znaków towarowych był usytuowany w Warszawie, podlegający bezpośrednio Ministrowi Przemysłu i Handlu - Urząd Patentowy ${ }^{22}$, na którego czele stał Prezes Urzędu Patentowego, mianowany przez Prezydenta RP (na wniosek Rady Ministrów przedstawiony przez Ministra Przemysłu i Handlu). Urząd dzielił się na poszczególne wydziały (Prezydialny, Zgłoszeń, Spraw Spornych, Odwoławczy oraz Kontroli Wykonywania Wynalazków), którymi kierowali naczelnicy (mianowani przez Ministra Przemysłu i Handlu na wniosek Prezesa Urzędu). Pondato w skład osobowy Urzędu wchodzili radcowie (stali i niestali) oraz sędziowie sądu okręgowego i apelacyjnego w Warszawie ${ }^{23}$. W postępowaniu przed Urzędem Patentowym strony mogły występować osobiście lub mogły być zastępowane przez adwokatów i rzeczników patentowych ${ }^{24}$.

Do właściwości Wydziału Zgłoszeń należały wszystkie sprawy dotyczące znaków towarowych, jeżeli nie zastrzeżono ich rozstrzygnięcia innemu wydziałowi (art. 201 ust. 1). W szczególności należały tutaj sprawy o rejestrację znaków (art. 193-199 i art. 201) 25. Przeciwko rozstrzygnięciu Wydziału Zgłoszeń służyło odwołanie do Wydziału Odwoławczego (art. 200, art. 202).

Sprawy o unieważnienie zarejestrowanego znaku towarowego (art. 183, 192, 203-206, 224 ust. 3) i umorzenie znaku towarowego (art. 222) oddano do kompetencji Wydziału Spraw Spornych. Postępowanie przed tym wydziałem nieco przypominało postępowanie sądowe, gdyż występowały tutaj dwie strony (powodowa i pozwana), a po wniesieniu pism przygotowawczych w wydziale tym odbywała się jawna, ustna rozprawa. Podmiotem uprawnionym do wnoszenia skarg w interesie publicznym była Prokuratoria Generalna. Orzeczenia Wydziału Spraw Spornych można było zaskarżyć do Wydziału Odwoławczego (art. 208 i 209).

$\mathrm{Na}$ podstawie art. 210 przeciwko rozstrzygnięciom Urzędu Patentowego (ściślej Wydziału Odwoławczego) można było jeszcze wnosić skargi do Najwyższego Trybunału Administracyjnego, o ile rozstrzygnięcia te podle-

obu znaków, lecz wymagane jest zacieranie się różnic między obu znakami w umyśle odbiorcy, który ma w pamięci znak dawniejszy. Natomiast w wypadkach dalej sięgających różnic, wychodzących poza ramy art. 181, a mogących jednak wprowadzić w błąd odbiorców co do pochodzenia towaru lub jego rodzaju itp. ochronę prawną przewiduje art. 177 ust. 1 lit c), oczywiście przy zachodzących po temu warunkach".

21 Rejestrowania, sprawowania nadzoru i publicznoprawnej kontroli nad wykonywaniem należnych praw.

22 Urząd Patentowy, wbrew nazwie, nie zajmował się tylko patentami na wynalazki. Jego działalność była znacznie szersza, gdyż dotyczyła również wzorów (użytkowych i zdobniczych) oraz znaków towarowych.

${ }^{23}$ Zob. bliżej art. 232-234 rozporządzenia.

24 Uregulowania dotyczące rzeczników patentowych zawarto w art. 240-243 rozporządzenia.

25 Zob. bliżej tabela na końcu tego opracowania. 
gały takiemu zaskarżeniu na mocy ustawy o NTA z dnia 3 sierpnia 1922 roku $^{26}$. W postępowaniu przed NTA strona niezadowolona z decyzji Urzędu Patentowego pozywała Wydział Odwoławczy tego Urzędu. Orzeczenia NTA kończyły postępowanie w sprawie, częstokroć zdarzało się, że były one jeszcze glosowane przez najwybitniejszych przedstawicieli doktryny ${ }^{27}$.

Opisane postępowanie graficznie ilustruje następujący schemat:

Wydzial Zgłoszeń .................................... >
Wydział Odwolawczy ........................ > NTA

odwołanie

Wydzial Spraw Spornych

Analizując orzecznictwo NTA ${ }^{28}$, zwłaszcza to z drugiej połowy lat 30., trzeba powiedzieć, że największą grupę drukowanych orzeczeń stanowiły wyroki rozstrzygające o podobieństwie znaków. Wyraźnie widać ukształtowaną i konsekwentnie prezentowaną linię orzeczniczą, zgodnie z którą podobieństwo znaków towarowych polegało, bez względu na różnice szczegółów, na ogólnym wrażeniu wzrokowym, zdolnym wprowadzić w błąd nabywcę co do pochodzenia towaru. Nie stanowiło to w żadnej mierze odejścia od literalnego brzmienia art. 181 rozporządzenia $^{29}$.

Niektóre sprawy wyłączono spod właściwości Urzędu Patentowego (Wydziału Zgłoszeń i Wydziału Spraw Spornych) i oddano sądom powszechnym (sądom okręgowym). Granica między właściwością Urzędu Patentowego a sądów wynikała z zasady, że spory dotyczące ważności i granic stosowania zarejestrowanego znaku rozstrzygał Urząd Patentowy natomiast roszczenia wynikające ze sporów o prawa i roszczenia prywatnoprawne (na przykład o własność i inne prawa rzeczowe, o wydanie wzbogacenia) oddano właściwości sądów powszechnych. Powagę rozstrzygnięć Urzędu Patentowego w postępowaniach o ochronę znaków towarowych potwierdzają tezy wyroków SN, jak choćby:

26 Tekst jedn. Dz.U. RP z 1926 r. Nr 68, poz. 400.

27 Zob. przykładowo glosy F. Zolla do orzeczeń nr 2099, 2129, 2175 czy S.M. Grzybowskiego do orzeczenia nr 2177, „Orzecznictwo Sądów Najwyższych w sprawach podatkowych i administracyjnych" 1938, t. 1, s. 83-90; 152-155; 246-247; 252-253.

28 Drukowane w miesięczniku „Orzecznictwo Sądów Najwyższych” w sprawach podatkowych i administracyjnych.

29 Art. 181: „Za znak taki sam w rozumieniu niniejszego rozporządzenia uważa się także znak różniący się od dawniejszego tak nieznacznie, że mimo różnic odbiorca towaru może z łatwością przypuszczać, iż towar pochodzi z przedsiębiorstwa, którego znak ma w pamięci”. 


\section{1. z dnia 22 września 1933 roku - III. 2 C. 492/32:}

$\mathrm{O}$ unieważnieniu prawa $\mathrm{z}$ rejestracji znaku towarowego, o tożsamości znaku $\mathrm{w}$ ramach art. 226 i o odpadnięciu warunków jego istnienia orzekać może tylko Urząd Patentowy. Jak długo orzeczenia takiego nie ma, nieuzasadnione są w sądzie powszechnym roszczenia z powodu niedozwolonego używania takiego znaku bez względu na to, czy oparte są na przepisach o znakach towarowych (art. 174 i nast. rozp. z 22.03.1928), czy też na normach o zwalczaniu nieuczciwej konkurencji [...] lub o oznaczeniu pochodzenia niektórych towarów krajowych w wewnętrznym handlu detalicznym [...], a wreszcie na przepisach kodeksu cywilnego. Tak długo bowiem, jak brak jest wspomnianego orzeczenia Urzędu Patentowego, wywiera znak zarejestrowany pełne skutki w myśl art. 174 rozp. z 22.03.1928 i używanie jego nie może uchodzić jako działanie uchybiające przytoczonym przepisom $^{30}$;

\section{2. z dnia 25 czerwca 1936 roku - 3 K. 653/36:}

W myśl art. 184 rozp. o ochronie wynalazków, wzorów i znaków towarowych, prawo z rejestracji znaku towarowego gaśnie, jeżeli warunki istnienia prawa z czasem odpadły i okoliczność ta zostanie stwierdzona prawomocnym orzeczeniem Urzędu Patentowego. Z tego wynika, że dokąd orzeczenie takie nie zapadnie, wyłączność z zarejestrowania znaku towarowego obowiązuje przeciw wszystkim pod sankcją $\mathrm{z}$ art. $188-190$ tego rozp. [... $]^{31}$.

Uchwały w Wydziale Zgłoszeń zapadały, co od zasady, za zgodą dwóch radców $^{32}$. W Wydziale Spraw Spornych orzeczenia zapadały większością głosów w składach złożonych z trzech członków, z których jeden musiał być sędzią sądu okręgowego. Natomiast w Wydziale Odwoławczym decyzje podejmowano większością głosów w kolegiach złożonych z trzech członków (w przypadku odwołań od uchwał Wydziału Zgłoszeń) albo w kolegiach pięcioosobowych (w przypadku odwołań od uchwał Wydziału Spraw Spornych) ${ }^{33}$.

Urząd Patentowy prowadził rejestry, które jako księgi publiczne dostępne były dla wszystkich. Przedmiotem wpisu, co do znaków towarowych, były między innymi informacje dotyczące rejestracji czy unieważnienia znaku. Wpis następował na podstawie uchwały właściwego wydziału. Ponadto informacje o zarejestrowaniu czy unieważnieniu znaku zawierało wydawane przez Urząd Patentowy czasopismo „Wiadomości Urzędu Patentowego”.

Jak już wspomniano, celem nabycia prawa wyłączności na znaku, powinien on być zgłoszony do rejestracji w Wydziale Zgłoszeń Urzędu Patentowego ${ }^{34}$,

30 Orzeczenie opublikowano w „Ruchu Prawniczym, Ekonomicznym i Socjologicznym” 1934, I półrocze, s. 211.

31 Orzeczenie publikuje T.H. Godłowski, Orzecznictwo do kodeksu handlowego i przepisów związkowych. Ochrona wynalazków, wzorów i znaków towarowych, Kraków-Warszawa 1939, s. $3-4$.

32 Zob. bliżej art. 235 ust. 1 i 2 rozporządzenia.

33 W kolegiach przewodniczył Prezes Urzędu Patentowego lub jego zastępca, a jednym z członków miał być sędzia sądu apelacyjnego (art. 235 ust. 4).

34 Szczegółowe przepisy w tym zakresie zawierało obwieszczenie Prezesa Urzędu Patentowego Rzeczypospolitej Polskiej z dnia 27 marca 1931 roku o przepisach obowiązujących przy zgłaszaniu wynalazków, wzorów i znaków towarowych (część III. Przepisy dotyczące zgłaszania znaków towarowych do zarejestrowania — §§ 12-16), „Wiadomości Urzędu Patentowego” 1931, 
gdzie badany był pod kątem formalnym, czyli sprawdzano zawartość zgłoszenia w świetle wymogów wynikających z art. 194 i 195 rozporządzenia ${ }^{35}$. Ponadto badano zgłoszenie w kierunku braku przeciwwskazań do rejestracji wynikających z art. 174 i 177 rozporządzenia (art. 198 ust. 1), jak również odmawiano rejestracji, gdy ustalono, że zgłaszany znak był identyczny ze znakiem wcześniej zgłoszonym lub zarejestrowanym odnośnie do tego samego rodzaju towarów $\left(\right.$ art. 198 ust. 3) ${ }^{36}$. Natomiast jeżeli badanie przebiegło pomyślnie, Wydział Zgłoszeń wzywał zgłaszającego do dopełnienia kilku czynności technicznych (między innymi dokonania stosownych opłat), następnie zarządzał rejestrację znaku i wydawał świadectwo ochronne (art. 199 ust. 1) ${ }^{37}$. Jeśli już zarejestrowany znak nie odpowiadał wymogom ważności, podlegał unieważnieniu na podstawie art. 183. Szczególne przepisy zawarto w rozporządzeniu na wypadek, gdyby zgłoszony lub zarejestrowany znak był identyczny z niezarejestrowanym znakiem znanym już na ziemiach polskich jako należącym do innego przedsiębiorstwa wytwarzającego lub sprzedającego towary tego samego rodzaju. Przedsiębiorca posługujący się niezarejestrowanym znakiem (tak zwany używacz uprzedni ${ }^{38}$ ) mógł w ciągu roku od rejestracji znaku, zgłosić żądanie do Urzędu Patentowego, a w razie sporu do sądu, o uznanie prawa do znaku za jego prawo i przepisanie znaku na rzecz jego przedsiębiorstwa (art. 180). Jednak, co zauważyła już polska doktryna międzywojenna, jeżeli chodziło o skargi o unieważnienie prawa z rejestracji wytaczane przed Urzędem Patentowym w sytuacji, gdy jako strona występował używacz faktyczny przeciwko posiadaczowi prawa z rejestracji, Urząd Patentowy nie zakreślał żadnego terminu i unieważniał prawo nabyte z rejestracji znaku,

z. 3, poz. 21, s. 126-130. Regulacje te weszły w życie z dniem 1 maja 1931 roku, zastępując dotychczasowe obwieszczenie Prezesa Urzędu Patentowego Rzeczypospolitej Polskiej z dnia 27 kwietnia 1928 roku o przepisach obowiązujących przy zgłaszaniu wynalazków, wzorów i znaków towarowych (część III. Przepisy dotyczące zgłaszania znaków towarowych do zarejestrowania $\S \S 12-15)$, „Wiadomości Urzędu Patentowego” 1928, z. 4, poz. 37, s. 316-319.

35 Urząd Patentowy (ściślej Wydział Zgłoszeń) sprawdzał, czy zgłoszenie zawiera wszystkie prawem przewidziane elementy.

36 Sytuację tę znakomicie ilustruje wyrok NTA z dnia 2 stycznia 1936 roku (1. rej. 4675/33) w sprawie firmy Towarzystwo Handlu Herbatą „Aromat” Władysław Szenfeld i Sp. w Warszawie przeciw Wydziałowi Odwoławczemu Urzędu Patentowego w przedmiocie rejestracji znaku towarowego. Firma na oznaczenie herbaty zgłosiła znak towarowy przedstawiający stylizowany rysunek czajnika i trzech szklanek w kole z napisem „herbata aromat”. Wydział Zgłoszeń Urzędu Patentowego odmówił zarejestrowania zgłoszonego znaku, uznając go w części rysunkowej i słownej za taki sam jak wcześniej zarejestrowane znaki innych firm. Wydział Odwoławczy zatwierdził uchwałę Wydziału Zgłoszeń, a NTA oddalił skargę Towarzystwa Handlu Herbatą „Aromat” Władysław Szenfeld i Sp. w Warszawie. Zob. bliżej „Orzecznictwo Sądów Najwyższych w sprawach podatkowych i administracyjnych” 1937, t. 2, orzeczenie nr 1886, s. 616-617.

37 Dopiero od tego momentu znak był traktowany jako zarejestrowany (chroniony na podstawie rozporządzenia) i udzielano mu prawa wyłączności. Zob. bliżej J. Gumiński, Wyłączność znaków towarowych, „Głos Sądownictwa” 1930, nr 9, s. 526.

38 W doktrynie posługiwano się również terminem „używacz faktyczny”. 
nawet wówczas gdy skargę wniesiono już po upływie roku od zawiadomienia o rejestracji znaku. Dopuszczalność takiej praktyki przewidywał przywołany komentarz do prawa patentowego Polskie prawo patentowe. Rozporzadzenie... autorstwa A. Ponikło i J. Gutowskiego ${ }^{39}$. Jak się wydaje, intencją ustawodawcy było przekazanie Urzędowi Patentowemu jurysdykcji w sprawach prostych, w których rozstrzygnięcie było oczywiste. Spory bardziej skomplikowane, wymagające badania ważności tytułu nabycia prawa do znaku w myśl art. 180 ust. 1 zostały oddane orzecznictwu sądów powszechnych. Tymczasem praktyka Urzędu Patentowego rozszerzyła się w tym kierunku, że poza sprawami prostymi Urząd orzekał również w sprawach charakteryzujących się znacznie większym stopniem skomplikowania. R. Paszkowski ${ }^{40}$ pisał:

Skargi używaczy faktycznych o unieważnieniu prawa z rejestracji są rozpoznawane w Urzędzie Patentowym nie tylko wtedy, gdy znak używacza jest notorycznie znany, ale i wówczas, gdy rzekomy używacz faktyczny, usiłujący wzruszyć prawo nabyte przez rejestrację, legitymuje się tylko zwykłem wprowadzeniem znaku w ograniczonym okręgu lub okręgach Polski. Dopuszczane są wtedy przez Urząd Patentowy różne dowody, a więc dowody ze świadków: pracowników stron będących w sporze, grawerów, którzy w swoim czasie wykonywali klisze znaków, przedsiębiorców dostarczających etykiety, opakowania itd. stronom spór wiodącym; wreszcie zasięgane są opinie sfer fachowych, izb przemysłowo-handlowych i na podstawie tego materiału wyprowadzane są wnioski o prawie do $\mathrm{znaku}^{41}$.

Jego zdaniem Urząd Patentowy swoim działaniem wchodził w kompetencje sądów. Ten sam autor posługuje się przykładem z orzecznictwa:

Na podstawie opinii sfer fachowych, zebranych za pośrednictwem Izb Przem. Handl. z całego niemal obszaru ziem polskich ustalił Wydz. Spraw Spornych, że znak towarowy, używany (bez rejestracji) przez skarżącą firmę dla oznaczania chustek na głowę, a przedstawiający napis „Cosmanos” znany jest w Małopolsce wschodniej od lat kilkudziesięciu, na Górnym Śląsku od lat 20, na Śląsku Cieszyńskim od lat 15, w pozostałych zaś częściach Polski od lat kilkunastu, a co najmniej (w okręgu Lubelskim) od lat 6, natomiast zarejestrowany znak pozwanej firmy z napisem „Cosmos” znany jest w niektórych okolicach Polski od lat kilku zaledwie, w innych zaś wcale nie jest znany. Z powyższego wynika, że przeciwko rejestracji spornego znaku „Cosmos” zachodzi przeszkoda z artykułu 177 ust. 1c i dlatego prawo z rejestracji tego znaku należy uznać za nieważne ${ }^{42}$.

Tym samym Urząd Patentowy rozpoznał sprawę, która w myśl przepisów wchodziła w zakres kognicji sądów powszechnych.

Jak widać pomimo istnienia odpowiednich regulacji prawnych zawartych w rozporządzeniu o ochronie wynalazków, wzorów i znaków towarowych z 1928 roku, praktyka urzędowo-sądowa podążała czasami w innym, nieprzewidzianym przez ustawodawcę kierunku.

39 Zob. bliżej R. Paszkowski, op. cit., s. 19.

40 Adwokat, były stały radca prawny Urzędu Patentowego.

41 R. Paszkowski, op. cit., s. 19.

42 Ibidem, s. 43. 
Tabela 1. Statystyka za lata 1928-1939 zgłoszonych i zarejestrowanych w Urzędzie Patentowym znaków towarowych ${ }^{43}$

\begin{tabular}{|c|c|c|}
\hline Rok & $\begin{array}{c}\text { Liczba zgłoszonych } \\
\text { znaków krajowych }\end{array}$ & $\begin{array}{c}\text { Liczba zarejestrowanych } \\
\text { znaków krajowych }\end{array}$ \\
\hline 1928 & 1395 & 834 \\
\hline 1929 & 1411 & 967 \\
\hline 1930 & 1279 & 847 \\
\hline 1931 & 1198 & 760 \\
\hline 1932 & 1170 & 779 \\
\hline 1933 & 1350 & 736 \\
\hline 1934 & 1472 & 589 \\
\hline 1935 & 1453 & 719 \\
\hline 1936 & 1609 & 968 \\
\hline 1937 & 1659 & 582 \\
\hline 1938 & 1600 & 600 \\
\hline 1939 & 880 & 678 \\
\hline łącznie & 16476 & 9059 \\
\hline
\end{tabular}

\section{Bibliografia}

\section{Akty prawne}

Konwencja związkowa paryska o ochronie własności przemysłowej z dnia 20 marca 1883 roku, przejrzana w Brukseli dnia 14 grudnia1900 roku, w Waszyngtonie dnia 2 czerwca 1911 roku i w Hadze dnia 6 listopada 1925 roku (Dz.U. RP z 1932 r. Nr 2, poz. 8).

Dekret tymczasowy o Urzędzie Patentowym z dnia 13 grudnia 1918 roku (Dz.P. P. P. nr 21, poz. 66).

Dekret o ochronie wzorów rysunkowych i modeli z dnia 4 lutego 1919 roku (Dz.P.P.P. nr 13, poz. 138).

Dekret o ochronie znaków towarowych z dnia 4 lutego 1919 roku (Dz.P.P.P. nr 13, poz. 139).

Dekret o patentach na wynalazki z dnia 4 lutego 1919 roku (Dz.P. P. P. nr 13, poz. 137).

Ustawa o zmianach w dekrecie o Urzędzie Patentowym z dnia 2 sierpnia 1919 roku (Dz.P.P.P. nr 67, poz. 410).

Ustawa o Najwyższym Trybunale Administracyjnym z dnia 3 sierpnia 1922 roku (tekst jedn. Dz.U. RP z 1926 r. Nr 68, poz. 400).

Ustawa o ochronie wynalazków, wzorów i znaków towarowych z dnia 5 lutego 1924 roku (Dz.U. RP Nr 31, poz. 306).

43 Źródło: „Wiadomości Urzędu Patentowego” z lat: 1931, z. 3, s. 167-168; 1933, z. 1, s. 12; 1934 , z. 1 , s. 9; 1935 , z. 1, s. 16 ; 1936, z. 1, s. $11 ; 1937$, z. 1, s. 6 ; 1938, z. 1, s. 12; 1939, z. 1, s. 14; 1940 , z. 4, s. $102 ; 1940$, z. 6, s. 169-170. 
Ustawa o zmianach opłat przewidzianych w ustawie z dnia 5 lutego 1924 roku o ochronie wynalazków, wzorów i znaków towarowych z dnia 19 grudnia 1924 roku (Dz.U. RP z 1925 r. Nr 5, poz. 41).

Ustawa o zwalczaniu nieuczciwej konkurencji z dnia 2 sierpnia 1926 roku (tekst jedn. Dz.U. RP z 1930 r. Nr 56, poz. 467).

Rozporządzenie Prezydenta Rzeczypospolitej zmieniające niektóre postanowienia ustawy z dnia 5 lutego 1924 roku o ochronie wynalazków, wzorów i znaków towarowych z dnia 24 czerwca 1927 roku (Dz.U. RP Nr 61, poz. 537).

Rozporządzenie Prezydenta Rzeczypospolitej o ochronie wynalazków, wzorów i znaków towarowych z dnia 22 marca 1928 roku (Dz.U. RP Nr 39, poz. 384).

Obwieszczenie Prezesa Urzędu Patentowego Rzeczypospolitej Polskiej z dnia 27 kwietnia 1928 roku o przepisach obowiązujących przy zgłaszaniu wynalazków, wzorów i znaków towarowych, „Wiadomości Urzędu Patentowego” 1928, z. 4, poz. 37.

Ustawa ratyfikująca konwencję związkową paryską z dnia 17 marca 1931 roku (Dz.U. RP Nr 37, poz. 277).

Obwieszczenie Prezesa Urzędu Patentowego Rzeczypospolitej Polskiej z dnia 27 marca 1931 roku o przepisach obowiązujących przy zgłaszaniu wynalazków, wzorów i znaków towarowych, „Wiadomości Urzędu Patentowego” 1931, z. 3, poz. 21.

\section{Literatura}

Czaykowski S., Ochrona własności przemystowej i handlowej, [w:] Polityka gospodarcza. Zagadnienia administracji, t. 1, Warszawa 1928.

Czempińska W., Rozwój pojęć o ochronie praw wynalazcy, Warszawa 1931.

Dolata T., Geneza, budowa i ważniejsze rozwiąania ustawy o ochronie wynalazków, wzorów i znaków towarowych z dnia 5 lutego 1924 roku, „Studia Historycznoprawne” 315/2, 2013.

Dolata T., Początki polskiego ustawodawstwa z zakresu ochrony wynalazków, wzorów i znaków towarowych $w$ dwudziestoleciu międzywojennym, „Studia Historycznoprawne” 314, 2012.

Dolata T., Polska ustawa o zwalczaniu nieuczciwej konkurencji z 1926 r., a inne regulacje z zakresu praw na dobrach niematerialnych, [w:] Studia z dziejów państwa i prawa polskiego, t. 12, Kraków-Lublin-Łódź 2009.

Dwa przemówienia w Sejmie Ministra Przemystu i Handlu inż. Eugeniusza Kwiatkowskiego, [w:] Polityka gospodarcza. Zagadnienia administracji, t. 1, Warszawa 1928.

Godłowski T.H., Orzecznictwo do kodeksu handlowego i przepisów związkowych. Ochrona wynalazków, wzorów i znaków towarowych, Kraków-Warszawa 1939.

Górnicki L., Prawa na dobrach niematerialnych, [w:] Synteza prawa polskiego 1918-1939, red. T. Guz., J. Głuchowski, M.R. Pałubska, Warszawa 2013.

Górnicki L., Rozwój idei ochrony praw własności intelektualnej do II wojny światowej, „Zeszyty Naukowe Wyższej Szkoły Informatyki i Zarządzania »Copernicus« we Wrocławiu”, 2006, nr 3.

Górnicki L., Wpływ obcych ustawodawstw i doktryny prawa na polska kodyfikacje prawa prywatnego w II RP, [w:] Korzenie i tradycje wspótczesnego prawa cywilnego w zjednoczonej Europie, red. A. Karabowicz, M. Stus, („ZNUJ. Towarzystwo Biblioteki Słuchaczów Prawa. Zeszyty Prawnicze” z. 13), Kraków 2005, s. 73-74.

Gruszow L., Rozwój działalności urzędów patentowych, [w:] Księga pamiątkowa z okazji 85-lecia ochrony własności przemystowej w Polsce, red. E. Wikło, Warszawa 2003.

Grzybowski S.M., Ochrona wynalazków, wzorów i znaków towarowych, „Encyklopedia Podręczna Prawa Prywatnego", [b.m.w., b.r.w.], odbitka, z. 18 i 19.

Gumiński J., Wyłaczność znaków towarowych, „Głos Sądownictwa” 1930, nr 9.

Hausner R., Skorowidz dekretów, ustaw, rozporządzeń i okólników, t. 1. Warszawa 1920.

Mieroszewicz E.S., Ustawa o ochronie wynalazków, wzorów i znaków towarowych, Warszawa 1924.

Prawo 325, 2018

(C) for this edition by CNS 
Paszkowski R., Powstanie prawa do znaku towarowego a ustawa o zwalczaniu nieuczciwej konkurencji, Warszawa 1935.

Ponikło A., Gutowski J., Polskie prawo patentowe. Rozporzadzenie Prezydenta Rzeczypospolitej $z$ dnia 22 marca 1928 r. o ochronie wynalazków, wzorów i znaków towarowych. Komentarz z przedmowa $i$ wstępem prof. d-ra Fryderyka Zolla, Warszawa 1935.

Słomski M., Historia rzecznictwa patentowego w Polsce, Kraków 1997.

Zoll F., Opinja prawna profesora dra Fryderyka Zolla o prawie firmy Maggi do wytacznego używania charakterystycznych flaszek w handlu przyprawa do zup, Poznań 1931.

Zoll F., Prawa na dobrach niematerialnych, [w:] Encyklopedia Podręczna Prawa Publicznego, t. 2, red. Z. Cybichowski, Warszawa [b.r.w.].

\title{
The Patent Office and the protection of trade marks under the 1928 Regulation on the Protection of Inventions, Designs and Trademarks - an outline
}

\author{
Summary
}

The aim of the paper is to discuss the work of the Patent Office with regard to the protection of trademarks under the 1928 Regulation on the Protection of Inventions, Designs and Trademarks. Given the long period it remained in force, the Regulation is the most reliable basis for investigating the matter. What remains outside the scope of the paper is a detailed discussion of the theoretical constructs used by the legislator to protect trademarks. Although these questions are obviously connected with the subject matter in question, they constitute a separate research problem.

Keywords: industrial property, trademark, trademark law in the Second Polish Republic, Patent Office in the Second Polish Republic

\section{Die Tätigkeit des Patentamtes im Bereich des Schutzes der Warenzeichen auf Grund der Verordnung über den Schutz von Erfindungen, der Muster und Warenzeichen aus dem Jahre 1928 Umriss der Problematik}

\section{Zusammenfassung}

Ziel dieser Bearbeitung ist die Besprechung der Tätigkeit des Patentamtes im Bereich des Schutzes der Warenzeichen unter der Verordnung betreffend den Schutz von Erfindungen, der Muster und Warenzeichen aus dem Jahre 1928. Diese Verordnung in Anbetracht der längsten Geltungszeit stellt die maßgebliche Grundlage für die Untersuchung dieser Problematik. Außerhalb dieser Bearbeitung bleibt die detaillierte Besprechung der Angelegenheiten betreffend die theoretischen Konstruktionen, die vom Gesetzgeber für den Schutz der Warenzeichen genutzt werden. Zwar verbinden sich diese Angelegenheiten offensichtlich mit der besprochenen Problematik, sie stellen jedoch ein abgetrenntes Forschungsthema dar.

Schlüsselworte: gewerbliches Eigentum, Warenzeichen, Recht der Warenzeichen in der Zweiten Polnischen Republik, Patentamt der Zweiten Polnischen Republik 